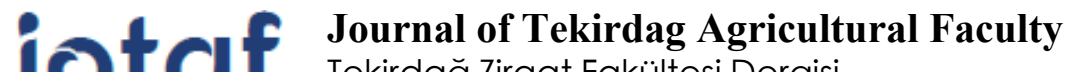 \\ Tekirdağ Ziraat Fakültesi Dergisi
}

\section{Yield and Yield Components of White Lupine Under Different Ecological Conditions}

\author{
Vivien PÁL ${ }^{1}$, Oqba BASAL ${ }^{1 *}$, Zsuzsa ERDŐS ${ }^{1}$, Szilvia VERES ${ }^{2}$, László ZSOMBİK ${ }^{1}$
}

\begin{abstract}
White lupine (Lupinus albus L.), with its favorable agrotechnical specifications, is a very important legume. Its water demand is relatively low, yet fluctuations in water amount and/or distribution during its life cycle might influence its performance. An experiment was carried out at 3 locations in Hungary; "Debrecen", "Jobbágyi" and "Nyalka" in 2020 to investigate certain yield components performance; namely pod number plant ${ }^{-1}$, seed number plant $^{-1}$, seed weight plant ${ }^{-1}$ and 1000-seed weight, as well as the final seed yield of white lupine (cv. Nelly). In addition, the average seed size (calculated as a percentage from the final seed yield) was also calculated. Soil was slightly alkaline in "Nyalka", whereas it was acidic in the other 2 locations. Precipitation was higher in "Debrecen" from April to July. Results showed that "Debrecen" location had significantly higher pod number plant ${ }^{-1}$, seed number plant ${ }^{-1}$ and seed weight plant ${ }^{-1}$, leading to significantly higher seed yield compared to "Jobbágyi" and "Nyalka" locations. Seed yield was strongly-positively correlated with most of the seed component traits. In addition, "Debrecen" location had the highest average of bigger seeds (over $9 \mathrm{~mm}$ ) and the lowest average of smaller seeds (between $3.5-9 \mathrm{~mm}$ ). It could be concluded that white lupine performance in the study areas is highly associated with both the precipitation amount and distribution throughout the plant's vegetative period, as well as with the soil $\mathrm{pH}$. More thorough studies concerning potential enhancements in white lupine's growth and yield with the availability of specific nourishers might be an additional database enrichment, especially with the lack of such data in the studied areas.
\end{abstract}

Keywords: Climate sensitivity, Lupine, Pod number, Precipitation, Soil pH

\footnotetext{
${ }^{1}$ Vivien Pal, University of Debrecen, Institutes for Agricultural Research and Educational Farm, Research Institute of Nyíregyháza, Nyíregyháza, Hungary. E-mail: pal.vivien@agr.unideb.hu (iD) OrcID: 0000-0003-1831-5695.

1*Sorumlu Yazar/Corresponding Author: Oqba Basal, University of Debrecen, Institutes for Agricultural Research and Educational Farm, Research Institute of Nyíregyháza, Nyíregyháza, Hungary. E-mail: oqba@agr.unideb.hu (iD OrcID: 0000-0002-2396-6591.

${ }^{1}$ Zsuzsa Erdös, University of Debrecen, Institutes for Agricultural Research and Educational Farm, Research Institute of Nyíregyháza, Nyíregyháza, Hungary. Email: erdoszs@agr.unideb.hu (D) OrcID: 0000-0001-6618-0217.

2 Szilvia Veres, University of Debrecen, Faculty of Agricultural and Food Sciences and Environmental Management, Debrecen, Hungary. E-mail: szveres@agr.unideb.hu (iD) OrcID: 0000-0003-4509-789X.

${ }^{1}$ Laszlo Zsombik, University of Debrecen, Institutes for Agricultural Research and Educational Farm, Research Institute of Nyíregyháza, Nyíregyháza, Hungary. E-mail: zsombik@agr.unideb.hu (iD) OrcID: 0000-0003-0908-0302.

Atıf/Citation: Pal V., Basal O., Erdös Z., Veres S., Zsombik L. Yield and Yield Components of White Lupine Under Different Ecological Conditions. Tekirda $\breve{g}$ Ziraat Fakültesi Dergisi, 18 (4), 730-738.

CBu çalışma Tekirdağ Namık Kemal Üniversitesi tarafından Creative Commons Lisansı (https://creativecommons.org/licenses/by-nc/4.0/) kapsamında yayınlanmıştır. Tekirdağ 2021
} 


\section{Introduction}

Species belonging to Fabaceace plant family are well known to be the best forecrop for cereal monocultures, especially with the fact that these species fix atmospheric nitrogen (Gan et al. 2015). Although much of fixed $N$ is used by the legume itself, yet the rest can be exploited by successive cereal, leading to enhanced protein content (Armstrong et al. 1997; Kalembasa et al. 2014).

Lupine is one of the most important legumes, as some of its species are consumed by humans, while others are used in animal feeding either as green forage or as protein supplements in the form of grains. Moreover, it can be used as a green manure. It has low phosphorus demand, and the crude protein content (300-500 $\left.\mathrm{g} \mathrm{kg}^{-1}\right)$ and oil (50$100 \mathrm{~g} \mathrm{~kg}^{-1}$ ) is high (Bolland and Brennan, 2008; Calabrò et al., 2015; Huyghe, 1997).

Although water requirements for lupines are not high, yet they are reported to be susceptible to water deficiency and to grow better in moist, non-waterlogged soils with pH of 7 or less (Polit et al., 2019; Rashad et al., 2018). However, different species of lupine were reported to respond differently to weather unfavorable conditions occurring during the growing season (Dracup et al., 1998; Gresta et al., 2017).

White lupine (Lupinus albus L.) is one of the four species of this genus (in addition to L. angustifolius, L. luteus, L. mutabilis). It can be grown in a wide soil-type range (Weisskopf et al., 2006). Its pods stay closed when matured, and can fairly stick to the stalks, resulting in minimal losses at harvest (Khalimullina et al., 2019). In addition, the growth rate of white lupine is rapid, especially during early growing stages, with $14-16{ }^{\circ} \mathrm{C}$ for vegetative organ formation and $16-20^{\circ} \mathrm{C}$ for anthesis as the optimum temperatures (Mazur et al., 2018).

In Hungary, the breeding of white-flowered sweet lupine species (Lupinus albus L.) was started in 1943 by Vilmos Teichmann. The breeding was justified by the recognition that few protein-rich fodder plants grow on acidic sandy soils, so sweet lupine could help with two major problems of crop production in weak soils; fodder shortage and soil replenishment, promoting more efficient farming (Borbély, 2003). In addition to high productivity and vigorous growth, the primary objective of breeding was low alkaloid content (Teichmann, 1952). The sweet lupine variety (Nelly) was granted state recognition in 1985, the main breeding objective of which was to increase drought tolerance and resistance to pathogens in addition to increasing nutritional parameters and productivity (Borbély, 2007). To our best knowledge, no English paper dealing with white lupine's growth and production under different conditions in the territory of Hungary was published, so this experiment aimed at studying the yield and yield components of white lupine (Lupinus albus L. cv. Nelly) in 3 different locations in Hungary with different soil and meteorological conditions.

\section{Materials and Methods}

This experiment aimed at evaluating the yield components and seed size ratios of lupine (Lupinus albus L. cv. Nelly) at 3 locations in Hungary (Figure 1); namely: Debrecen (47.549164, 21.456522), Jobbágyi (47.820811, 19.668177) and Nyalka (47.555106, 17.795270).

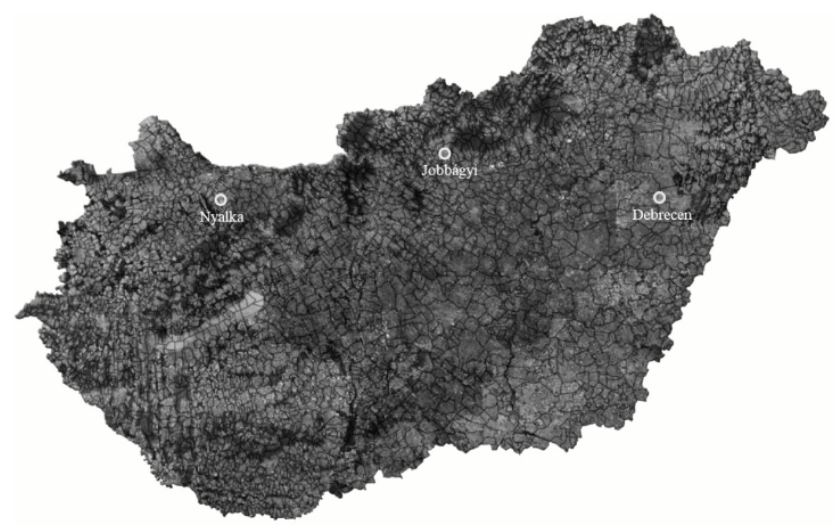

Figure 1. Experimental locations of white lupine yield performance, Hungary, 2020

The soil type in "Jobbágyi" and "Nyalka" locations is luvisol, whereas the soil type in "Debrecen" is chernozem. Soil chemical analysis was carried out before sowing, and results are shown in Table 1. 
Pal \& Basal \&Erdös \& Veres \& Zsombik Yield and Yield Components of White Lupine Under Different Ecological Conditions

Table 1. Soil chemical analysis in Jobbágyi, Nyalka and Debrecen locations, Hungary, 2020

\begin{tabular}{|c|c|c|c|}
\hline Location & Jobbágyi & Nyalka & Debrecen \\
\hline $\mathrm{pH}(\mathrm{KCl} 1: 2,5)[-]$ & 4.95 & 7.38 & 5.34 \\
\hline Arany-type plasticity index $\left[\mathrm{K}_{\mathrm{A}}\right]$ & 44.82 & 35.85 & 37.52 \\
\hline Total soluble salt content $[\mathrm{m} / \mathrm{m} \%]$ & 0.02 & $<0.02$ & $<0.02$ \\
\hline Carbon content $[\mathrm{m} / \mathrm{m} \%]$ & $<0.1$ & 2.61 & $<0.1$ \\
\hline Organic matter content $[\mathrm{m} / \mathrm{m} \%]$ & 1.49 & 1.46 & 2.26 \\
\hline Nitrogen-nitrit+nitrate ( $\mathrm{KCl}$ soluble) $\left[\mathrm{mg} \mathrm{kg}^{-1} \mathrm{~d} . \mathrm{m}\right]$ & 10.42 & 4.75 & 5.15 \\
\hline Magnesium ( $\mathrm{KCl}$ soluble) $\left[\mathrm{mg} \mathrm{kg}^{-1} \mathrm{~d} . \mathrm{m}\right]$ & 277.43 & 102.10 & 230.30 \\
\hline Sulfur ( $\mathrm{KCl}$ soluble) $\left[\mathrm{mg} \mathrm{kg}^{-1} \mathrm{~d} . \mathrm{m}\right]$ & 3.71 & 1.34 & 1.45 \\
\hline Potassium-oxide (AL-soluble) $\left[\mathrm{mgkg}^{-1} \mathrm{~d} . \mathrm{m}\right]$ & 250.51 & 212.39 & 418.28 \\
\hline Natrium (AL-soluble) $\left[\mathrm{mg} \mathrm{kg}^{-1} \mathrm{~d} . \mathrm{m}\right]$ & 26.61 & 20.96 & 21.13 \\
\hline Phosphorus-pentoxide (AL-soluble) $\left[\mathrm{mg} \mathrm{kg}^{-1} \mathrm{~d} . \mathrm{m}\right]$ & 39.98 & 136.94 & 355.30 \\
\hline $\mathrm{Cu}(\mathrm{KCl}-\mathrm{EDTA}$ soluble $)\left[\mathrm{mg} \mathrm{kg}^{-1} \mathrm{~d} . \mathrm{m}\right]$ & 4.28 & 2.15 & 3.36 \\
\hline $\mathrm{Mn}\left(\mathrm{KCl}\right.$ - EDTA soluble) $\left[\mathrm{mgkg}^{-1} \mathrm{~d} . \mathrm{m}\right]$ & 326.27 & 135.17 & 347.40 \\
\hline $\mathrm{Zn}\left(\mathrm{KCl}\right.$ - EDTA soluble) $\left[\mathrm{mg} \mathrm{kg}^{-1} \mathrm{~d} . \mathrm{m}\right]$ & 0.94 & 0.68 & 1.27 \\
\hline
\end{tabular}

In "Jobbágyi", soil $\mathrm{pH}$ was 4.95 , indicating acidic soil dominance. In addition, soil plasticity (44.82 $\mathrm{K}_{\mathrm{A}}$ ) was the highest among all locations. The organic matter content was low. Nitrogen content was low compared to the other locations. Potassium-oxide content was high. Phosphorus was very low compared to the other experimental sites.

In "Nyalka", soil pH was neutral (7.38). Plasticity index was medium $\left(35.85 \mathrm{~K}_{\mathrm{A}}\right)$. Organic matter content was very similar to "Jobbágyi" location (1.46\%). Nitrogen content was low (4.25 $\left.\mathrm{mg} \mathrm{kg}^{-1}\right)$. Potassium content was high (219.39 $\left.\mathrm{mg} \mathrm{kg}{ }^{-1}\right)$. Phosphorus content was medium (136.94 $\left.\mathrm{mgkg}^{-1}\right)$.

In "Debrecen", soil $\mathrm{pH}$ was acidic (5.34). Soil plasticity index was close to "Nyalka" $\left(37.52 \mathrm{~K}_{\mathrm{A}}\right)$. Organic matter content was the highest among the sites (2.26\%). Nitrogen content was low. Potassium content was the highest among sites $\left(418.28 \mathrm{mg} \mathrm{kg}^{-1}\right)$. Phosphorus content was high $\left(355.3 \mathrm{mg} \mathrm{kg}^{-1}\right)$.

For the other nutrients, no measurable differences that would affect lupine development were detected.

The experiment was carried out during 2020 in a completely randomized design with 3 replications in "Debrecen" and 4 replications in "Nyalka" and "Jobbágyi".

In "Debrecen" and "Jobbágyi", the plot size was $22.5 \mathrm{~m}^{2}$, the row distance was $75 \mathrm{~cm}$ in both locations, with 3 rows per plot. Each plot was $10 \mathrm{~m}$ long. In "Nyalka", the plot size was $20 \mathrm{~m}^{2}$, with row distance of $50 \mathrm{~cm}$. Each plot had 4 rows of $10 \mathrm{~m}$ long.

In "Jobbágyi", the forecrop was winter wheat. Sowing date was $26^{\text {th }}$ of March. The seed rate was $105 \mathrm{~kg} \mathrm{ha}^{-1}$ $\left(350,000\right.$ seeds ha $\left.^{-1}\right)$. Simultaneously, $150 \mathrm{~kg} \mathrm{ha}^{-1}$ of DASA $(26 \% \mathrm{~N}, 13 \% \mathrm{~S})$ fertilizer was applied. The experimental site was inter-row cultivated twice. The plots were manually harvested at full maturity stage on $11^{\text {th }}$ of August.

In "Nyalka", the forecrop was hairy vetch, sowing date was $3^{\text {rd }}$ of April, with a seed rate of $140 \mathrm{~kg} \mathrm{ha}^{-1}$ (450 000 seeds ha ${ }^{-1}$. Inter-row cultivator was used 5 times and weed harrowing was applied 3 times in the lupine field to control weeds. Given that the area is bio-classified, no fertilizer was applied. The harvest was done by hand at full maturity stage on $8^{\text {th }}$ of August.

In "Debrecen", the forecrop was sweet corn. Before sowing, $300 \mathrm{~kg} \mathrm{ha}^{-1}$ MAS $(27 \% \mathrm{~N})$ fertilizer was applied. Sowing date was $04^{\text {th }}$ of April, with a seed rate of $105 \mathrm{~kg} \mathrm{ha}^{-1}(350000$ seeds ha-1). An inter-row cultivator was used three times. The harvest was manually done for each plot at full maturity stage on $18^{\text {th }}$ of August.

Weather conditions of the experimental sites during the growing period are shown in Figure 2. 


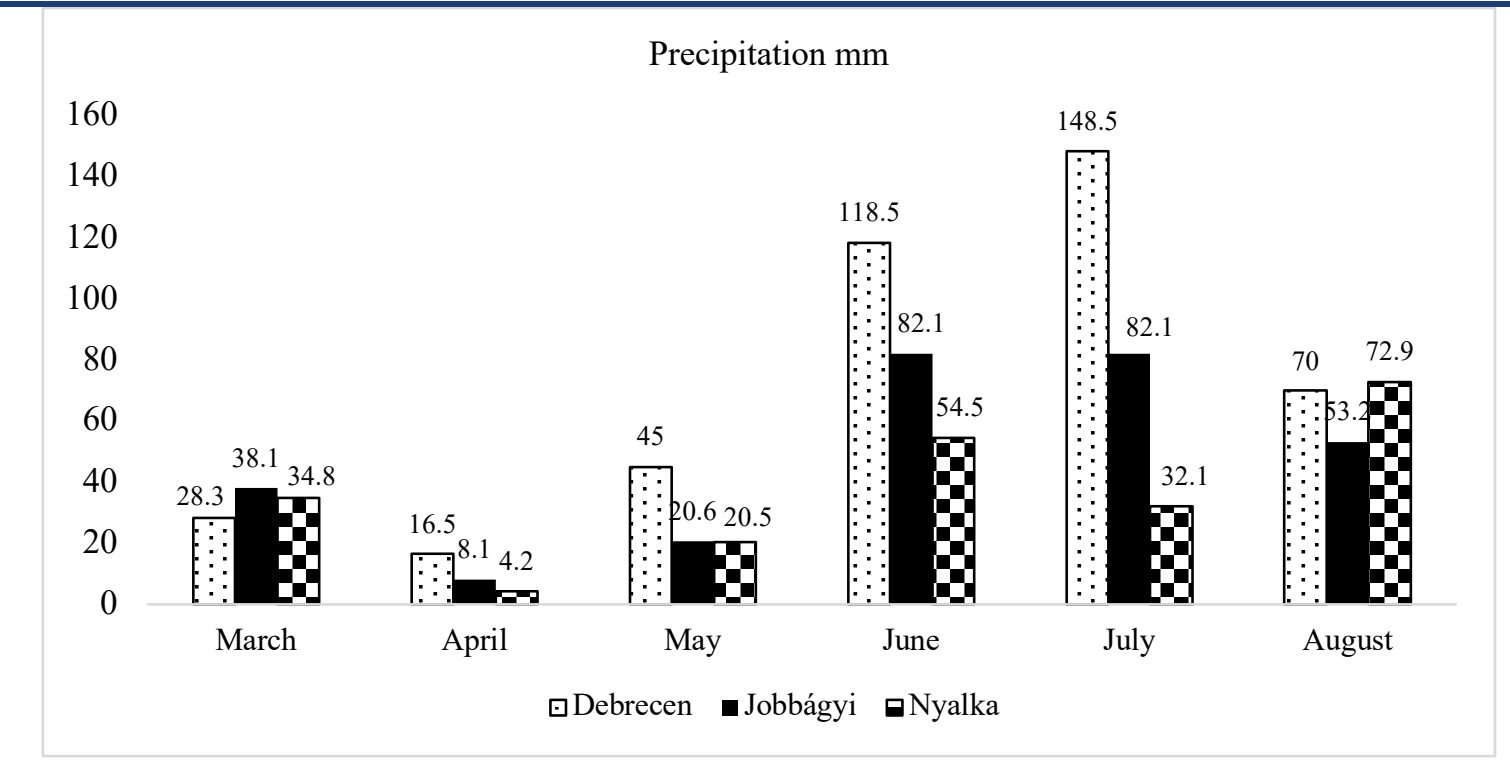

\section{Figure 2. Average precipitation(mm) in Jobbágyi, Debrecen and Nyalka during the growing period of lupine, Hungary 2020}

The total amount of precipitation in the growing season (from March to August) was almost two times more in "Debrecen" ( $426.8 \mathrm{~mm})$ than "Jobbágyi" $(284.2 \mathrm{~mm})$ and "Nyalka" $(219.0 \mathrm{~mm})$. During the period of germination and early development, a small amount of precipitation was recorded in "Jobbágyi" and "Nyalka"; only $8.1 \mathrm{~mm}$ and 4.2 $\mathrm{mm}$ in April, and $20.6 \mathrm{~mm}$ and $20.5 \mathrm{~mm}$ in May, respectively. By contrast, in "Debrecen" there was $16.5 \mathrm{~mm}$ of precipitation in April and $45 \mathrm{~mm}$ in May. In June and July, $118.5 \mathrm{~mm}$ and $148.5 \mathrm{~mm}$ of precipitation were recorded in "Debrecen", which was favorable for the vegetative development of lupine. In "Jobbágyi", the amount of precipitation in June and July proved to be satisfactory $(82.1 \mathrm{~mm})$, while in "Nyalka" there was $54.5 \mathrm{~mm}$ of precipitation in June, $40 \%$ of which was in one day $\left(14^{\text {th }}\right)$, and $32.1 \mathrm{~mm}$ in July.

As for evaluating the temperatures during the growing period, the highest number of hot days (average daily temperature higher than $25^{\circ} \mathrm{C}$ ) was recorded in "Nyalka" ( 1 day in June, 4 days in July, 3 days in August). In "Jobbágyi", 5 hot days occurred in August, while in "Debrecen" the average temperature only exceeded $25^{\circ} \mathrm{C}$ once in August.

Calculations of pod number plant ${ }^{-1}$, seed number plant ${ }^{-1}$, seed yield plant ${ }^{-1}$ were made by measuring each plant in each plot and then calculating the average value. Based on the collected plant samples (Debrecen: 1280 plants; Jobbágyi: 1767 plants; Nyalka: 1954 plants), the level of lupine yield was determined by the individual productivity of plants, which, in turn, depends on the amplitude of the change in the number of pods per plant and the mass of seeds on the stalk. The thousand-seed weight was determined on the basis of the seed weight and seed number harvested from the plots. The seeds were divided into different size fractions with a Kamas type sieve, the seeds were divided into size ranges larger than $9 \mathrm{~mm}$, between $9 \mathrm{~mm}$ and $3.5 \mathrm{~mm}$ and less than $3.5 \mathrm{~mm}$, then the ratio of different size fractions to total harvested yield were measured.

SPSS software (ver. 26, IBM, USA) was run to compare the means and analyze the variance among locations, followed by Tukey's post hoc analysis to indicate the significant differences where applicable, and Pearson's correlation test was run to indicate the correlation coefficient among the studied traits.

\section{Results and Discussion}

\subsection{Yield Components}

"Debrecen" location had significantly higher pod number plant ${ }^{-1}$, compared to "Jobbágyi" and "Nyalka". The pod number plant ${ }^{-1}$ in "Debrecen" was $62.2 \%$ and $140 \%$ higher compared to "Jobbágyi" and "Nyalka", respectively. Although "Jobbágyi" had relatively higher seed number plant ${ }^{-1}$ than "Nyalka", yet both locations had significantly lower seed number plant ${ }^{-1}$ (by $43 \%$ and $65 \%$, respectively) than the location in "Debrecen". "Nyalka" 
Pal \& Basal \&Erdös \& Veres \& Zsombik Yield and Yield Components of White Lupine Under Different Ecological Conditions produced the lowest seed weight $\left(\mathrm{g}\right.$ plant $\left.{ }^{-1}\right)$, whereas "Debrecen" had significantly higher seed weight $\left(\mathrm{g}\right.$ plant $\left.{ }^{-1}\right)$ than both "Jobbágyi" and "Nyalka" locations. "Jobbágyi" location had the lowest, whereas "Debrecen" had the highest 1000-seed Weight. However, the differences among the three locations were slight and insignificant (Table 2).

Table 2. Pod number, seed number, seed weight, seed yield and 1000-seed weight of white lupine in Debrecen, Jobbágyi and Nyalka, Hungary, 2020

\begin{tabular}{cccccc}
\hline Location & Pod Number plant & $\begin{array}{c}\text { Seed Number } \\
\text { plant }^{-1}\end{array}$ & $\begin{array}{c}\text { Seed Weight (g } \\
\left.\text { plant }^{-1}\right)\end{array}$ & $\begin{array}{c}\text { Seed Yield (kg } \\
\left.\text { ha }^{-1}\right)\end{array}$ & $\begin{array}{c}\text { 1000-seed } \\
\text { Weight (g) }\end{array}$ \\
\hline Debrecen & $12.0^{\mathrm{a}}$ & $43.9^{\mathrm{a}}$ & $12.7^{\mathrm{a}}$ & $2,378.3^{\mathrm{a}}$ & $279.5^{\mathrm{a}}$ \\
Jobbágyi & $7.4^{\mathrm{b}}$ & $25.0^{\mathrm{b}}$ & $6.7^{\mathrm{b}}$ & $1,315.4^{\mathrm{b}}$ & $264.1^{\mathrm{a}}$ \\
Nyalka & $5.0^{\mathrm{b}}$ & $15.3^{\mathrm{b}}$ & $4.1^{\mathrm{b}}$ & $1,001.4^{\mathrm{b}}$ & $276.1^{\mathrm{a}}$ \\
\hline
\end{tabular}

- Different letters within each trait indicate significant difference at .05 level among locations. $\mathrm{n}=3$

\subsection{Seed Yield $\left(\mathrm{kg} \mathrm{ha}^{-1}\right)$}

"Debrecen" location produced significantly higher seed yield (kg ha-1) than all other locations. The seed yield in "Debrecen" was $80.8 \%$ and $137.5 \%$ higher than in "Jobbágyi" and "Nyalka", respectively. "Nyalka" had the lowest seed yield. Averaged over all locations, seed yield was strongly-positively correlated with all seed component traits, with the exception of 1000-seed weight (where the correlation was still positive, yet not strong). Moreover, the correlation was strong and positive with the bigger seed size, but strong and negative with the smaller seed size (Table 3).

Table 3. Correlation coefficients (average over all locations) among the examined parameters

\begin{tabular}{|c|c|c|c|c|c|c|c|}
\hline & $\begin{array}{c}\text { Pod } \\
\text { Number } \\
\text { plant }^{-1}\end{array}$ & $\begin{array}{c}\text { Seed } \\
\text { Number } \\
\text { plant }^{-1}\end{array}$ & $\begin{array}{c}\text { Seed } \\
\text { Weight } \\
\text { plant }^{-1}\end{array}$ & $\begin{array}{c}\text { Thousand } \\
\text { Seed Weight } \\
\left(\mathrm{g} \text { plant }{ }^{-1}\right)\end{array}$ & $\begin{array}{c}\text { Yield } \\
\left(\mathrm{kg} \mathrm{ha}^{-1}\right)\end{array}$ & $\begin{array}{l}\text { Average seed } \\
\text { size over } 9 \\
\text { mm }(\%)\end{array}$ & $\begin{array}{l}\text { Average seed } \\
\text { size between } \\
3,5-9 \mathrm{~mm}(\%)\end{array}$ \\
\hline $\begin{array}{c}\text { Pod Number } \\
\text { plant }^{-1} \\
\text { Seed }\end{array}$ & 1 & $.992^{* *}$ & $.979^{* *}$ & .031 & $.678^{*}$ & $.712^{* *}$ & $-.708^{* *}$ \\
\hline $\begin{array}{c}\text { Number } \\
\text { plant }^{-1}\end{array}$ & $.992^{* *}$ & 1 & $.993^{* *}$ & .039 & $.720^{* *}$ & $.747^{* *}$ & $-.744^{* *}$ \\
\hline $\begin{array}{l}\text { Seed Weight } \\
\text { plant }^{-1}\end{array}$ & $.979^{* *}$ & $.993^{* *}$ & 1 & .133 & $.777^{* *}$ & $.792^{* *}$ & $-.790^{* *}$ \\
\hline $\begin{array}{l}\text { 1000-Seed } \\
\text { Weight } \\
\left(\text { g plant }^{-1}\right)\end{array}$ & .031 & .039 & .133 & 1 & .294 & .363 & -.364 \\
\hline $\begin{array}{l}\text { Seed Yield } \\
\quad\left(\mathrm{kg} \mathrm{ha}^{-1}\right)\end{array}$ & $.678^{*}$ & $.720^{* *}$ & $.777^{* *}$ & .294 & 1 & $.734^{* *}$ & $-.737^{* *}$ \\
\hline $\begin{array}{c}\text { Average } \\
\text { seed size } \\
\text { over } 9 \mathrm{~mm} \\
(\%)\end{array}$ & $.712^{* *}$ & $.747^{* *}$ & $.792^{* *}$ & .363 & $.734^{* *}$ & 1 & $-1.000^{* *}$ \\
\hline
\end{tabular}

*. Correlation is significant at the 0.05 level (2-tailed).

**. Correlation is significant at the 0.01 level (2-tailed).

\subsection{Average Seed Size (\%)}

The highest average of bigger seeds (over $9 \mathrm{~mm}$ ) and the lowest average of smaller seeds (between $3.5-9 \mathrm{~mm}$ ) was recorded in "Debrecen" location, where the difference was significant compared to the other locations, followed by "Nyalka" and "Jobbágyi", respectively (Table 4). The bigger seed size was strongly correlated with all traits except for the correlation with the 1000-seed weight, where the correlation was still normal and with the smaller seed size where it was negative (Table 3). 
Table 4. Ratio of different seed sizes at the studied locations, Hungary, 2020

\begin{tabular}{ccc}
\hline Location & Average seed size over $9 \mathrm{~mm}(\%)$ & Average seed size between $3,5-9 \mathrm{~mm}(\%)$ \\
\hline Debrecen & $59.3^{\mathrm{a}}$ & $40.1^{\mathrm{b}}$ \\
Jobbágyi & $25.4^{\mathrm{b}}$ & $74.0^{\mathrm{a}}$ \\
Nyalka & $33.2^{\mathrm{b}}$ & $66.4^{\mathrm{a}}$ \\
\hline
\end{tabular}

- Different letters within each trait indicate significant difference at .05 level among locations.

\section{Discussion}

\subsection{Yield Components}

Our results showed that "Nyalka" had the lowest yield among the three studied locations, where the soil pH was the highest (Table 1). It was previously reported that the growth rate of white lupine (cv. Alban) plants was significantly reduced with increasing the nutrient solution $\mathrm{pH}$. As a result, the shoot biomass significantly decreased (to $1.79 \mathrm{~g} \mathrm{plant}^{-}$ ${ }^{1}$ ) when the solution's $\mathrm{pH}$ was 7.5 , relative to 5.5 and 6.5 where the biomass gradually, yet insignificantly, decreased to 2.38 and 2.20 g plant $^{-1}$, respectively. The highest biomass $\left(2.39 \mathrm{~g} \mathrm{plant}^{-1}\right)$ was achieved under the solution's $\mathrm{pH}$ conditions of 4.5 (Bertoni et al., 1992). Earlier, Bertoni et al. (1990) reported similar conclusion.

Both the 1000-seed weight and the pod number plant ${ }^{-1}$ can vary based on the available water for plants (Podleśna et al. 2014), which is supported by our findings. The higher pod number plant ${ }^{-1}$ resulted in higher seed yields of different white lupine cultivars (Borowska et al., 2015). We also found a significant correlation $(\mathrm{r}=0.678)$ (Table 3) between pod number plant ${ }^{-1}$ and seed yield. Khalimullina et al. (2019) reported that precipitation deficiency during the late stages of white lupine (variety Gamma) caused pod number plant ${ }^{-1}$ to decrease by $5.5 \%$. They also reported that the same variety had the seed number plant ${ }^{-1}$ decreased by $23 \%$, the seed weight plant ${ }^{-1}$ decreased by $34.6 \%$ and the 1000 seed weight decreased by $15.2 \%$ under this unfavorable condition. Similarly, "Degas" variety decreased seed number plant $^{-1}$ by $3.9 \%$, seed weight plant ${ }^{-1}$ by $24.8 \%, 1000$-seed weight by $22.1 \%$. Our results showed that pod number plant ${ }^{1}$, seed number plant ${ }^{-1}$ and seed weight plant ${ }^{-1}$ significantly decreased under water shortage conditions, whereas the 1000-seed weight did not measurably vary (Figure 2, Table 2). Different narrow-leafed lupine and yellow lupine varieties showed different reactions in terms of 1000-seed weight under terminal water deficiency conditions (Palta et al., 2007). However, Rashad et al. (2018) evaluated the influence of different water availability schemes on lupine (Lupinus termis L., cv. Giza 2) yield and its components under different compost rates in a sandy soil. The authors concluded that the 1000 -seed weight decreased by $9.1 \%$ (averaged over all compost rates) when water availability was decreased.

\subsection{Seed Yield and Seed Quality}

Precipitation amount and distribution during the plant's vegetation period is a vital factor that affects the final seed yield of legumes (Podleśna et al. 2014), especially if accompanied by increased temperatures during the late stages, as a result of its negative effect on flowering and podding (Atkins and Smith, 2004; Basal and Szabó, 2020). Similar conclusion was reported by Palta et al. (2007), who indicated that annual legumes are most susceptible to water deficiency during flowering stage. The same authors attributed the yield enhancement under better water availability during flowering and podding stages mainly to increased pod number as a result of increased lateral branch number. In our experiment, water shortage occurred basically during the late season (July) in "Nyalka", probably leading to reduced seed yield (Table 2). Khalimullina et al. (2019) reported a 37.4\% decrease in the seed yield of "Gamma" white lupine under unfavorable precipitation conditions.

There is high correlation between the yield quantity and/or quality and meteorology (Wilmowicz et al., 2019). Süheri et al. (2020) reported linear correlations between the seasonal water use and the final yield of snap bean. Polit et al. (2019) indicated that although the enhancement (by 25.1\%) of the seed yield of a yellow lupine variety (Mister) was not significant under well-watered conditions, yet the quality of the plants that got irrigation water was visually of much higher quality. Our results also showed that seed quality, in terms of seed size, in "Debrecen" was significantly higher than the other locations. On the other hand, narrow-leaved lupine that was grown during the same period and under the same water availability conditions reported by Polit et al. (2019) yielded 2.5 times more than the other group 
which did not get sufficient water, but with reduced seed size and weight (Winnicki et al., 2019).

Not only precipitation amounts and distribution, but also soil characteristics, particularly soil $\mathrm{pH}$ and limestone content, were reported to affect the yield components of white lupine by influencing the efficiency of the symbiosis process, leading to major yield reduction and $\mathrm{N}_{2}$ fixation (Sulas et al., 2015). Kerley (2000) reported a 30\% yield decrease in white lupine when soil $\mathrm{pH}$ exceeded 7.2 and attributed this decrease to shoot growth restrictions. Our results showed that the seed yield in "Nyalka" location $(\mathrm{pH}=7,38)$ was significantly less compared to that of "Debrecen" location, where the soil pH was lower (5.34). Vlachostergios et al. (2016) conducted experiments in two locations with different soil characteristics, one location with optimal $\mathrm{pH}$ (equal to 6.5), and one location was considered as the stress $\mathrm{pH}$ level (equal to 8.1). Their results showed that the mean yield in the optimum environment ranged from 1.4 to 4.12 $\mathrm{t} \mathrm{ha}^{-1}$, while under high $\mathrm{pH}$ conditions the yield mean was measurably lower $\left(0.2-1.5 \mathrm{tha}^{-1}\right)$. The authors also indicated that the mean seed yield per single plant of the trial was $5.2 \mathrm{~g}$ under optimum circumstances, whereas it ranged from 1.8-4.6 $\mathrm{g}$ under stress conditions.

\section{Conclusions}

It could be concluded that the precipitation amount and distribution throughout the vegetative period of white lupine had a measurable effect on the yield components measured, resulting in significant differences in the final seed yield. Not only the precipitation, but also the soil $\mathrm{pH}$ played a role, as even a mildly-alkaline soil negatively affected all the studied traits, leading to the lowest yield among all locations. Further investigations of the influence of certain nutrients availability for white lupine plants under favorable soil and climatic conditions will probably enrich the knowledge database of this important legume.

\section{Acknowledgment}

This paper and the research behind it would not have been possible without the financial support of the EIP-AGRI application "VP 3.-16.1.1. Különböző termesztési körzetekben előállított édes csillagfürt alternatív fehérjeforrásként történő vizsgálata és ökonómiája a sertéstenyésztésben”. 


\section{References}

Armstrong, E.L., Heenan, D.P., Pate, J.S., Unkovich, M.J. (1997). Nitrogen benefits of lupins, field pea, and chickpea to wheat production in south-eastern Australia. Australian Journal of Agricultural Research, 48: 39-48.

Atkins, C.A., Smith, P.M. (2004). Regulation of pod set and seed development in lupin. In: van Santen E., Hill G.D. (eds.): Proceedings of the $10^{\text {th }}$ International Lupin Conference, 19-24. June 2002, New Zealand, 275-278.

Basal, O., Szabó, A. (2020). Yield and Quality of Two Soybean Cultivars in Response to Drought and N Fertilization. Tekirdağ Ziraat Fakültesi Dergisi, 17(2): 203-210.

Bertoni, G., Mouloungui, D., Kaemmerer, M., Morard, P. (1990). Effect of some soil characteristics on white lupine (Lupinus albus L) mineral nutrition, growth and yield. In: A. Scaife (ed.) Proceedings First Congress, Europoan Society of Agronomy (Paris, December 5-7, 1990), Colmar, France, 34.

Bertoni, G.M., Pissaloux, A., Morard, Ph., Sayag, D.R. (1992). Bicarbonate-pH relationship with iron chlorosis in white lupine. Journal of Plant Nutrition, 15(10): 1509-1518.

Bolland, M.D.A., Brennan, R.F. (2008). Comparing the phosphorus requirements of wheat, lupine, and canola. Aust J Agric Res, 59: $983-998$.

Borbély, F. (2003). Lupine breeding in Kisvárda. In: Iszályné, T.J. (ed.): The history of plant breeding in Kisvárda Jubilee publication 19432002: 81-89. (In Hungarian).

Borbély, F. (2007). Breeding and production of lupine (Lupinus sp. L.) species. In: Iszályné T.J. (ed.): $80^{\text {th }}$ anniversary Jubilee publication in University of Debrecen Center for Agricultural and Engineer Sciences Research, Nyíregyháza: 100-118. (In Hungarian).

Borowska, E., Prusinski, J., Kaszkowiak, E. (2015). Production results of intensification of cultivation technologies in three lupin (Lupinus L.) species. Plant Soil Environ., 61(9): 426-431.

Calabrò, S., Cutrignelli, M.I., Lo Presti, V., Tudisco, R., Chiofalo, V., Grossi, M., Infascelli, F., Chiofalo, B. (2015). Characterization and effect of year of harvest on the nutritional properties of three varieties of white lupine (Lupinus albus L.). Journal of the Science of Food and Agriculture, 95(15): 3127-3136.

Dracup, M., Turner, N.C., Tang, C., Reader, M., Palta, J. (1998). Responses to abiotic stresses. Chapter 8. In Lupins as Crop Plants: Biology, Production and Utilization; Gladstones, J.S., Atkins, C.A., Hamblin, J., Eds.; CABI: Wallingford, UK: 227-262.

Gan, Y.T., Hamel, C.T., O’Donowan, J.T., Cutforth, H., Zentner, R.P., Campbell, C.A., Niu, Y.N., Poppy, L. (2015). Diversifying crop rotations with pulses enhances system productivity. Scientific Reports, 5: 14-25.

Gresta, F., Wink, M., Prins, U., Abberton, M., Capraro, J., Scarafoni, A., Hill, G. (2017). Lupins in european cropping system. In: Legumes in Cropping System; Murphy-Bokern, D., Stoddard, F.L., Watson, C.A., Eds.; CABI Publishing: Wallingford, UK: 88-108.

Huyghe, C. (1997). White lupin (Lupinus albus L.). Field Crops Research, 53: 147-160.

Kalembasa, S., Wysokiński, A., Kalembasa, D. (2014). Quantitative assessment of the process of biological nitrogen reduction by yellow lupine (Lupinus luteus L.). Acta Scientiarum Polonorum seria Agricultura, 13: 5-20.

Kerley, S.J. (2000). The effect of soil liming on shoot development, root growth, and cluster root activity in white lupins. Biology and Fertility of Soils, 32(2): 94-101.

Khalimullina, A.A., Sozinov, A.V., Porsev, I.N., Subbotin, I.A. (2019). Productivity of white lupine (Lupinus albus L.) in different sowing periods in the conditions of the Southern Trans-Urals. In: IOP Conference Series: Earth and Environmental Science $341(1)$ : 012089.

Mazur, V.A., Mazur, K.V., Pantsyreva, H.V., Alekseev, O.O. (2018). Ecological and economic evaluation of varietal resources Lupinus albus L. in Ukraine. Ukrainian Journal of Ecology, 8(4): 148-153.

Palta, J.A., Turner, N.C., French, R.J., Buirchell, B.J. (2007). Water use efficiency physiological responses of lupin genotypes to terminal drought in a mediterranean-type environment. Annals of Applied Biology, 150: 269-279.

Podleśna, A., Podleśny, J., Doroszewski, A. (2014). Usefulness of selected weather indices to evaluation of yellow lupine yielding possibility. Agricultural Water Management, 146: 201-207.

Polit, J.T., Ciereszko, I., Dubis, A.T., Leśniewska, J., Basa, A., Winnicki, K., Żabka, A., Audzei, M., Sobiech, Ł., Faligowska, A., Skrzypczak, G. (2019). Irrigation-Induced Changes in Chemical Composition and Quality of Seeds of Yellow Lupine (Lupinus luteus L.). International journal of molecular sciences, 20(22): 5521.

Rashad, R.T., El-Agyzy, F.H., Abdel-Azeem, S.M. (2018). Impact of Irrigation Intervals on the Yield and Quality of Lupine (Lupinus termis L.) Grown in Sandy Soil Amended by an Organic Amendment. Asian Soil Research Journal: 1-11.

Süheri, S., Hussein, N.M.H., Kurtar, E.S., Yavuz, N. and Yeşim, D.A.L. (2020). Determination of Yield and Quality of Different Snap Bean Varieties Under Deficit Irrigation. Tekirdağ Ziraat Fakültesi Dergisi, 17(2): 252-263.

Sulas, L., Canu, S., Ledda, L., Carroni, A.M., Salis, M. (2015). Yield and nitrogen fixation potential from white lupine grown in rainfed Mediterranean. Scientia Agricola, 73(4): 338-346.

Teichmann, V. (1952). The issue of green manuring (comment). Scientific Council of Plant Breeding and Plant Breeding of Experimental Farms I-V. meeting material. (Compiled by Bánlaki, S.): 159. 
Pal \& Basal \&Erdös \& Veres \& Zsombik Yield and Yield Components of White Lupine Under Different Ecological Conditions

Vlachostergios, D.N., Divanes, I., Fyntanis, A., Koseoglou, E., Mavromatis, A.G. (2016). Selection of white lupine genotypes for yield and tolerance to alkaline soils. In: Kölliker, R., Boller, B., (eds) Plant Breeding: The Art of Bringing Science to Life. Abstracts of the 20 ${ }^{\text {th }}$ EUCARPIA General Congress. Zurich, Switzerland. 304.

Weisskopf, L., Abou-Mansour, E., Fromin, N., Tomasi, N., Santelia, D., Edelkott, I., Neumann, G., Aragno, M., Tabacchi, R., Martinoia, E. (2006). White lupin has developed a complex strategy to limit microbial degradation of secreted citrate required for phosphate acquisition. Plant, Cell and Environment, 29: 919-927.

Wilmowicz, E., Kućko, A., Burchardt, S., Przywieczerski, T. (2019). Molecular and hormonal aspects of drought-triggered flower shedding in yellow lupine. International journal of molecular sciences, 20(15): 3731.

Winnicki, K., Ciereszko, I., Leśniewska, J., Dubis, A.T., Basa, A., Żabka, A., Hołota, M., Sobiech, Ł., Faligowska, A., Skrzypczak, G., Maszewski, J. (2019). Irrigation affects characteristics of narrow-leaved lupin (Lupinus angustifolius L.) seeds. Planta, 249(6): 1731-1746. 